\title{
BIO DIVERSITY AND DENSITY OF PHYTOPLANKTON IN POND OF KIRTIPUR
}

\author{
Pramod Kumar Kushwaha \\ Department of Zoology, T.U., TRM Campus, Birgunj \\ Email: ompbaral@gmail.com
}

\begin{abstract}
The density of the phytoplankton during the study period was recorded 1420112 No. / L with the average value of 100150.3 No. / L fortnightly. All the four groups of phytoplankton were noted with low diversity of only 12 genera. The maximum density was found on 16th June 1992 (summer period) and the minimum on 25th Dec. 1991 (winter period). Among the four major groups, Chrysophyta (Bacillariophyceae) constituted $42.1 \%$ followed by Cyanophyta (Myxophyceae) 32.6\% , pyrrophyta (Desmidaceae) 18.5\% and Chlorophyta (Chlorophyceae) $6.8 \%$ respectively.

The free $\mathrm{CO}_{2}$ was positive coefficient value of phytoplankton in relation to temp., PH but dissolved oxygen had negative value of coefficient correlation.
\end{abstract}

\section{Keywords}

Population, Diversity, Density, Phytoplankton, Kirtipur, Nepal.

\section{Introduction}

Kirtipur is a very famous place of Nepal. It is a small town and historical place of Kathmandu district. It is situated in southwest of Kathmandu city at a distance of about $6 \mathrm{~km}$. Kirtipur lies on the hill near "Tribhuvan University". The town is famous for temples, shrines, University and people with their old traditional customs.

There are about 8 ponds situated in Kirtipur, the present man-made village pond named " Kirtipur Pukhu" is one of them. It is an old pond and its all four banks are bounded by stones. Kirtipur village pond is not so deep and was constructed for the multi-purposes such as bathing, drinking water for livestocks, 
cloth washing and may be for irrigation of crops and vegetable field.

The name "Kirtipur Pukhu" has come from Newari language "Pukhu" means pond. It is more or less rectangular in shape having the length of about 20-30 meters and breadth about 12.10 meters with an area of 245.63 sq. meters. This pond has not been well maintained. The bottom of the body is sandy clay.

Pond is a small and shallow body of water in which aquatic plants usually grow in abundance. It is different from the reservoir or lakes which is comparatively much bigger in size and depth. The accumulation of the water in natural manner forms a lake while it may be reservoir if created artificially. Similary a pond may have any dimension, although, a depth of more then 30 feet in a pond is rare to find. An ideal depth may be between $6-7$ feet from planktonic production point of view.

The phisico-chemical constituents such as light, depth, temperature, turbidity, $\mathrm{CO}_{2}$ , DO , $\mathrm{P}^{\mathrm{H}}$, alkalinity, hardness, nitrogen, carbohydrate, protein, fat, vitamins etc. of the water of a pond are very important for plankton production in the ponds which influence aquatic life in various ways.

Phytoplanktons are minute microscopic chlorophyll bearing organism or non-photosynthetic plants or saproplanktons passively floating in water and multiply rapidly which includes diatoms (Bacillariophyceae), blue green algae (mixophyceae), green algae (Chlorophyceae) and Desmidaceae.

In present study, the population density and diversity of phytoplankton and physicochemical parameters are carried out to contribute further knowledge about the phytoplanktonic production of pond.

\section{Methods and Materials}

The data was collected fortnightly. The standard methods after APHA ( 1976 ), Boyd ( 1979 ) and Adoni ( 1984 ) were followed for analysis of Physico-chemical parameters. For sampling and quantitative study Lacky's drop method ( Microtransect) method of APHA ( 1976 ) was followed. The quantitative analysis of phytoplankton was done with the help of Smith ( 1950 ), Edmondson ( 1959 ), Needham \& Needham ( 1962 ), Phillipose (1967) and some Chinese books.

\section{Results and Discussion}

The physico-chemical parameters observed in the field is presented in Table 1 . The different genera and their forthrightly fluctuation is given in Table 2. During the study period, 2 genera of chlorophyta, 2 genera of cyanophyta, 1 genus of pyrrophyta and 7 genera of chrysophyta, Total 12 genera were recorded ( Table 2 ). The bimonthly densities of all phytoplanktons were recorded. The total density and composition of chlorophyta, cyanophyta, chrysophyta and pyrrophyta phytoplankton is shown in Figure - A.

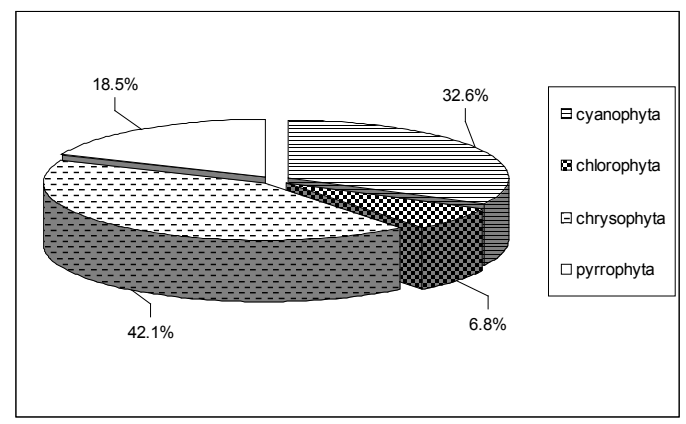

Figure - A

Pie-diagram showing phytoplankton density

The Chrysophyta (Bacillariophyceae) formed the major component of phytoplankton in the present study which contributed $42.1 \%$ of the total density. Similar type of dominancy of Bacillariophyceae over groups was also reported by Chackraborthy ( 1959 ) in river Yamuna and Shrestha ( 1982 ) in the upstream dam of Chisapani, Karnali river. The Phytoplanktonic density was peak in 


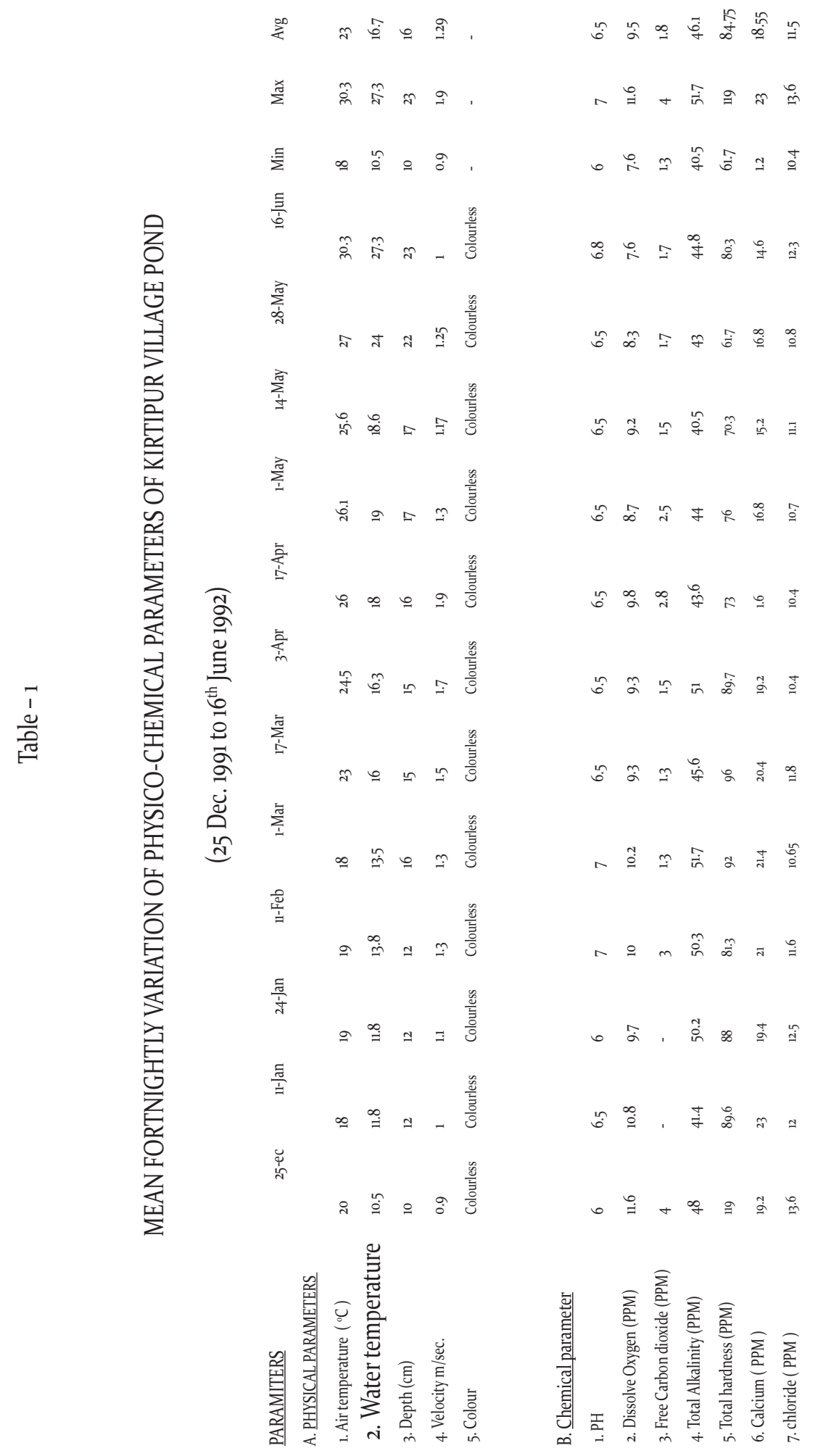


BIO DIVERSITY AND DENSITY OF PHYTOPLANKTON IN POND OF KIRTIPUR

总

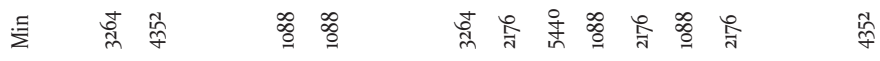

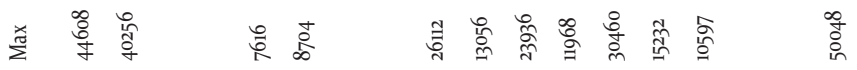

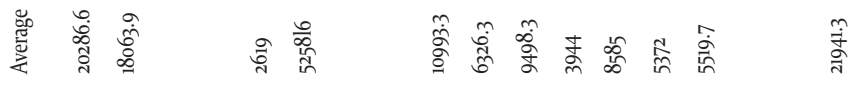

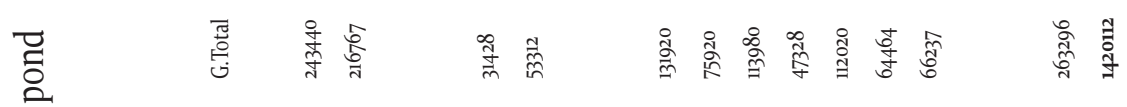

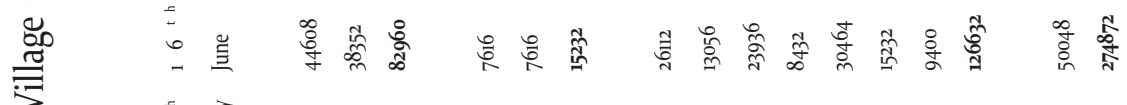

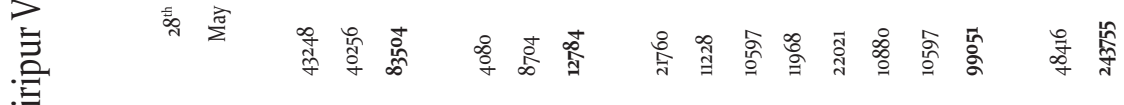

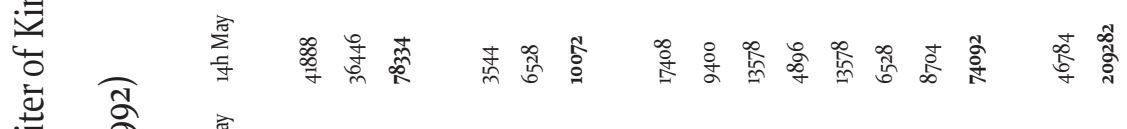

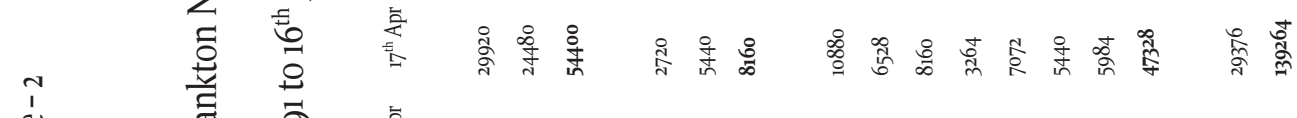

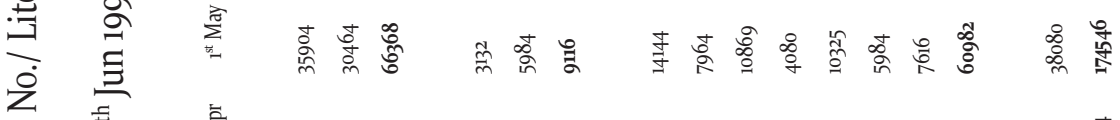

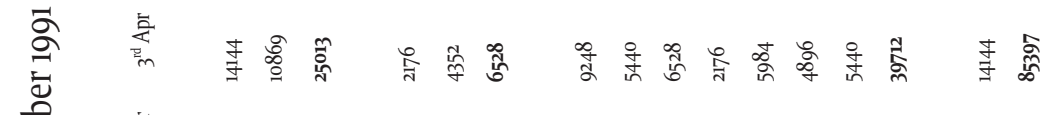

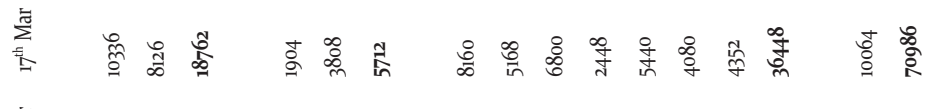

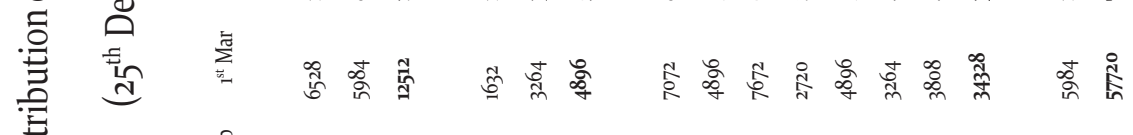

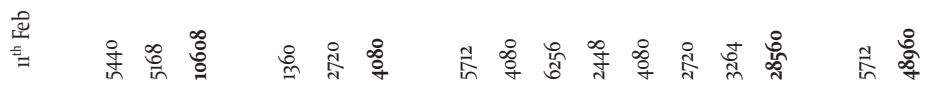

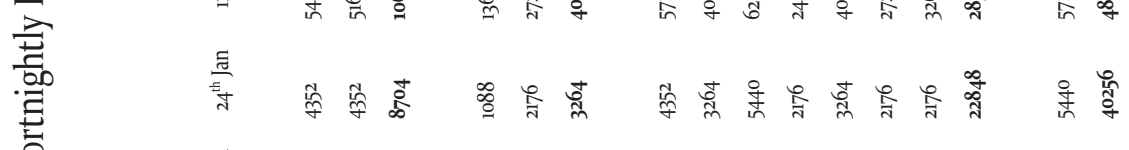

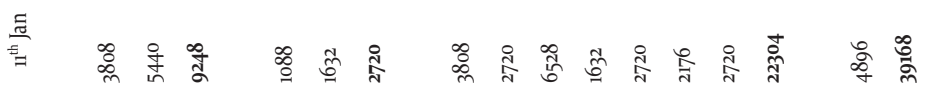

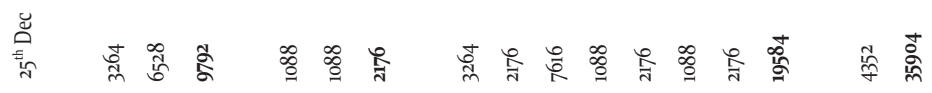

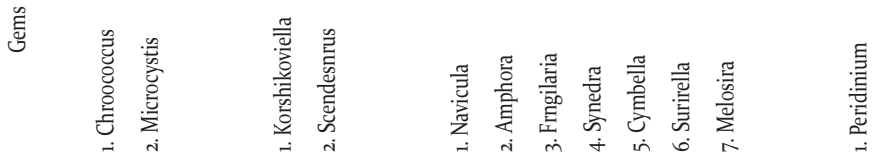

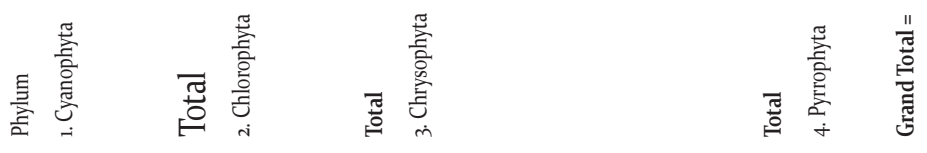


summer month of June. This type of finding was also reported by Chacko and Srinivasan (1955) in Godavari river of India. Further, they also noted the low diversity of phytoplankton which supports the present study.

The summer maxima or pick value of phytoplanktonic density is found to be maximum in June. It could be concluded from above results and discussion that lowest density was of Korshikoviella (Chlorophyta) and maximum of peridinium (pyrrophyta) in the bimonthy variation but in groupwise finding the Bacillariophyceae dominated other groups.

The low diversity of the phytoplankton may be due to the effect of different chemical and physical parameter of the pond water.

\section{Acknowledgement}

The author is thankful to Prof, Dr. Suresh Bahadur Karki Central Department of Zoology, Tribhuvan University, Kirtipur, Kathmandu for providing the facilities during the study.

\section{References}

Adony, A.D. (1984). Work book of limnology. Indian MAB Committee, Department of Environment, India.
APHA (1976). Standard methods for analysing water and waste water. American Public Health Publication, $14^{\text {th }}$ Edition, New York.

Boyd, C.E. ( 1979). Water quality in warm water fish pond. Auburn University, Albania.

Chacko, P.T. and Srinivasan, R. ( 1955 ). A Study of hydrobiology and fisheries of Adyar estuary with special reference to conservation. Cortr Freshw. Fish. Biol. Stru. Madras. ( 11 ).

Chackraborthy, R.D. (1959 ). A quantitative study of plankton and Physico-chemical conditions of the river Yamuna at Allahabad. India. Fish. 3.

Edmonson, W.T. (1959). Fresh water. II ${ }^{\text {nd }}$ Edition. New York : John Wiley and Sons Inc..

Needham, J.R. and Needham, P.R. (1962). A guide to fresh water biology. San Francisco: Folden day Inc..

Phillipose, M.T. (1967). Chloroccales, I.C. A. R. Monographs on algae 365pp.

Shrestha, J.S. (1982). Human Resource Development of Fisheries in Nepal.

Smith, G.N. (1950). Freshwater algae, United states. 